\title{
Whitman and Stevens in the U.K.: Some Personal Reflections
}

\author{
TONY SHARPE
}

1. How do Whitman and Stevens rank in British curricula? Are they considered essentially poetic equals or is there a significant difference in their status?

I'm unable to answer for the entirety of British university courses, but can respond in respect of those offered at my own institution, and those few with which I'm familiar through my work as an external examiner.

I don't think it would be true to say that Whitman and Stevens are considered "poetic equals," but, instead, that Whitman outranks Stevens, as a poet considered seminal to an understanding of American poetry, in a way that Stevens, with his difficult quirkiness, is not. Stevens, that is to say, is an acquired taste, whereas Whitman is a taste you are obliged to acquireas even Ezra Pound acknowledged when admitting he and Whitman had "one sap and one root" (in his poem "A Pact" [97]). Pound hadn't anything like the same fellow feeling toward Stevens, who provoked him to a multiplicity of question marks rather than a recognition of connection.

That represents my estimate of the general situation. To speak more personally, I regard Stevens as the jewel in the crown of twentieth-century American poetry (omitting transnationals like Eliot and Auden). I can re-read Stevens and discover "fresh transfigurings" (CPP 85) more readily than I can with Whitman, as it happens. The former seems inexhaustible, whereas the latter is on occasions exhausting (often by design).

2. How are Whitman and Stevens being taught in the U.K. today? Is one taught more than the other? Are they taught together?

I'd hope the answer to that first question is "well"! I can't easily answer the second without undertaking a survey, but imagine that each would be represented within their periods, with pos- 
sibly more time allotted to Whitman in his, typically, than to Stevens in twentieth-century courses, where, apart from anything else, the competition for inclusion is greater. There perhaps needs to be borne in mind the fact that some teachers, as well as more students, have an aversion from the readerly challenges Stevens sets that is not replicated when considering Whitman's invitational rhetoric. I doubt that the poets are frequently taught together, in part because of the predominant periodization that dissevers them. I would not, personally, find significant advantage in their conjunction: when I teach Whitman, I stress line and length and list, the democratization of the Emersonian mission, and see him as a poetic exponent of Thoreauvian "extra-vagance" as well as of an early American instinct toward self-publication and self-publicity. Stevens' relation to Emerson is more conflicted than Whitman's, though real enough, and temperamentally he seems closer to the austere, skeptically solitary, complex self-communings and committed visionary productivity of Emily Dickinson. Like hers, too, his musings were not unconnected with a position of social privilege. Sorry to put a firecat among your bucks, but when she declares to Thomas Wentworth Higginson, "There is always one thing to be grateful for, - that one is one's self and not somebody else" (xxi), I hear something Stevens could have said, and her four trees upon a solitary acre, following the course of their particularity, strike a premonitory Stevensian note that Whitman's live oak in Louisiana does not.

3. Is the link between twentieth-century American poetry and Whitman generally accepted?

I think that the success of Whitman's self-installation as the good g(r)ay father figure of American poetry is pretty universally acknowledged. His gender-friendliness diminishes the patriarchal oppressiveness that might accrue from such status, and, together with his genuinely moving work among the Unionist wounded, his "little souvenirs of camps and soldiers" (Whitman 605), recalls the Lincoln he so influentially mourned, as evoked in William Carlos Williams' vignette: “The least private would find a woman to caress him, a woman in an old shawl-with a great bearded face and a towering black hat above it, to give unearthly reality" (American 234). Robert Frost was the twentieth-century poet most obviously inheriting Whitman's public paternal mantle, while indicating his affiliation to Longfellow in the title of A Boy's Will. 
4. In teaching Stevens, how would you situate him in a Whitmanian American tradition?

This is, understandably enough, a leading question; but I wouldn't start from that premise nor necessarily aim to finish there. Although in 1939 Stevens sidestepped a questionnaire's assumption that a choice had to be made between Whitman and Henry James- "It is just as easy to be diffident about James as it is to be diffident about Whitman" (CPP 804)—my own way into Stevens is via the James who declared in a letter, "I hate American simplicity. I glory in the piling up of complications of every sort" (qtd. in Posnock 54): the Stevens, that is, who wrote "The Red Fern" rather than "The Red Wheelbarrow," and who enjoyed finding the longest rather than the shortest route between object and subject. The previous year, in responding to another questionnaire, he had hoped he would be registered as being an "American" writer, but not "flagrantly American" (CPP 800) - a phrase which, I would have thought, precisely encapsulates Whitman's poetic identity and project. Class enters into this: Stevens' final evocation of Whitman was of his riding in an open streetcar, either "lounging with one foot on the running-board" or-if "in back" — "he would have both feet on the rail" (CPP 879). That social insouciance Stevens grudgingly admired but could not altogether emulate. Whitman's "barbaric yawp" (247) may have its relation to Stevens' "jovial hullabaloo" (CPP 47), but there's a truly Jovial residue inhabiting and possibly even inhibiting the latter, which needs noticing-also heard, perhaps, when he confessed (in 1934!) to an "Inability to see much point to the life of an ordinary man"(CPP 771), which strikes a defiantly un-Whitmanian note. I rather fear that, were Stevens to have contemplated crowds spilling off the Brooklyn ferry, part of his linguistic response might have involved racist epithets (as in "The Drum-Majors in the Labor Day Parade," also from 1934); in a telling glimpse, Richard Wilbur recalls him standing appalled amidst the crowd of students heading toward his own poetry reading (Brazeau 168). That he summons Whitman as visionary forefather at the outset of his unpalatably titled sequence "Like Decorations in a Nigger Cemetery" has an ironic piquancy, in that Whitman's offenses against good taste were deliberate and strategic, whereas I do not believe Stevens wholly registers the offensiveness of the term he used. Yet part of the piquancy, also, derives from the fact that this phrase apparently reproduced the trenchant demotic of the poem's dedicatee, Judge Arthur Powell, and so has its authentically Whitmanian aspect. Of course, in a certain way Stevens 
saw all poetry as amounting to a decoration of our cemetery, and it could be argued that both poem and title acknowledge a defiant vigor in such aesthetic response (perhaps even substituting for those "peasant traditions" whose American absence Williams noted in "To Elsie" [217]).

Unlike Whitman with his sometimes coercive intimacy, Stevens, our "dark familiar" (CPP 119), is not a poet with whom we ever feel on comfortable first-name terms ("Friend and dear friend," perhaps [CPP 442], but never "two boys together clinging" [Whitman 282]). Here is another similarity to Dickinson, to whose tradition of American reclusiveness I sense Stevens' propinquity, inhabiting as he seems to have done an enormous loneliness (although "inhabiting an enormous loneliness" needs to be understood positively, as well as negatively). Both have their wildness, but sensing it depends on our acknowledging that both have their decorum. This latter quality, in her case, is what enables Billy Collins transgressively to imagine "Taking Off Emily Dickinson's Clothes"—an act absolutely pointless in the case of Whitman, "Disorderly fleshy and sensual," avid as he always is to get his kit off and "become undisguised and naked" $(50,27)$. "Walter [Arensberg] froze up when I spoke to him and when he froze up, I froze up too. ... Walter and I remained on our high horses. I never saw him again" ( $L$ 850): Stevens, like Dickinson, was a connoisseur of what it was to close the valves of one's attention and select one's own society. We seldom encounter in his poems anything resembling Whitman's ardent vocatives ("when I and you walk abroad upon the earth stung with compassion at the sight of numberless brothers answering our equal friendship" [17-18]), and it isn't easy to imagine Stevens writing a poem titled "Spontaneous $\mathrm{Me}^{\prime \prime}$ (spontaneity being something pejoratively associated with the "fops of fancy" [CPP 13]). When we do encounter such a mode, it stands out-as, for example: "Follow after, O my companion, my fellow, my self, / Sister and solace, brother and delight" (CPP 339). But Stevens' most ardent love poem addresses his Supreme Fiction (see CPP 329).

All that said, the Whitmanian note isn't necessarily to be found only in the work of those who, like Carl Sandburg or Allen Ginsberg, self-consciously set out to strike it; it could be said equally to influence the style of those who self-consciously set out to avoid it. When Whitman, skirting sierras and covering continents, is "afoot with [his] vision" (59), he sounds a grandly American sublime that Stevens sometimes replicates in miniature, through momentary epiphanies or ambiguous 
angels, or such exiguous utterance as is heard in "Life Is Motion," when Bonnie and Josie caper round their stump:

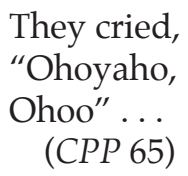

In this impoverished epithalamion "Celebrating the marriage / Of flesh and air" (CPP 65), we enjoy what Williams in his Autobiography claimed as the physician's privilege, "actually to witness the words being born" (361) —albeit in an "Oklahoma" that, like "Tennessee," seems to be one of Stevens' more problematical States. "Only the lull I like, the hum of your valved voice" (Whitman 30): the manifold evocations of voice in "Song of Myself" are always humanly located, whereas Stevens is intrigued and compelled, not only by the potential of "the voice that is great within us" (CPP 112), but by the implied subversive utterances of "the sound of the wind" (CPP 8; see also 77) and its "boo-ha" (CPP 410), or by the disputable "cry" of peacocks, ocean, and leaves (CPP 7, 105, 460). Although Stevens can simulate Whitmanian rhetoric in a poem of missionary statement like "Farewell to Florida," more characteristically his assertions are qualified (as Helen Vendler has suggested) and situated amid "the intricate evasions of as" (CPP 415).

Yet Stevens was aware, of course, of the planetary pull of Whitman, as of other nineteenth-century figures such as Thoreau, whose "plain-speaking transcendentalism" he evoked in a letter ( $L$ 436). In the spatialization of his own Americanness, Stevens rather more resembles Thoreau than Whitman, going on to declare, "One cannot help feeling that at the end of most of these abandoned roads the ghost of some early transcendentalist lives. I don't walk as much as I used to when I first came up here [Hartford], and there isn't any experience in any other part of the country quite like coming across an old orchard in the woods, or a path in the woods that was plainly a road, even if only a logging road, a century ago" ( $L$ 436). Ambulant Stevens, the young man who went for storming walks along the New Jersey Palisades, was still afoot with his particular vision in Hartford, forming poems on his pedestrian way to work. But if the truth depends on a walk around the lake, it might as well be a long one; his Hartford driver, Naaman Corn, sometimes encountered his employer in the wilder reaches of Keney Park, north of the city: 
He done walked from Westerly Terrace on over, and he walked all up through the park by himself, through the woods, any old place. He didn't care about snakes and things 'cause he had on walking shoes. He used to wear high-boot shoes all the time; he didn't wear the low-cut shoes. He had lighter ones when he was just coming to the office. (qtd. in Brazeau 55)

Stevens might well echo Thoreau's boast, having evidently traveled a good deal, in Hartford.

In "Beginning My Studies," Whitman links his ability to sing "ecstatic songs" to a refusal to go beyond "the first step" (171); but in "The Red Fern" and in many other poems, Stevens suggests the need to do just that. "Nomad Exquisite" is perhaps closest to "Beginning My Studies," but even here Stevens' logical and grammatical sequence is accumulative, in a progression Whitman's mode resists by ecstatic stasis. The impulse to "loiter" and "loafe" from which Whitman derived so rich a pay-off seems to be something different and less purposive than what Stevens defined as "The accent of deviation in the living thing / That is its life preserved" (CPP 459); nor do we find in him what William James derided as Whitman's "indiscriminate hurrahing for the universe" (289). There are undoubtedly some local connections, such as the probable audibility of Whitman's "Eighteen Sixty-One" ("No dainty rhymes or sentimental love verses for you terrible year, / Not you as some pale poetling seated at a desk lisping cadenzas piano" [418]) behind Stevens' "Mozart, 1935" (his only title to contain a date), with its injunction, "Poet, be seated at the piano. / Play the present" (CPP 107). Whitman's "eleves" perhaps prompted Stevens' "ephebe." A larger coherence suggests itself in Stevens' declarations, in "Materia Poetica" XXIII, that "All poetry is experimental poetry" (CPP 918), and, in a 1948 questionnaire, that "Poetry is nothing if it is not experiment in language" (CPP 823), which echo Whitman's comment, reported by Horace Traubel, that Leaves of Grass was "a language experiment." But here is an aspect in which Stevens may be more of an extremist in the exercise, for, according to Traubel, Whitman's exact phrase was "only a language experiment" (qtd. in Whitman, American viii-ix). Stevens, to whom "The gaiety of language is our seigneur" (CPP 284), would not have been so concessive.

Although, in a Whitmanian inclusiveness, Stevens' equivalent of il penseroso admits "things chalked / On the sidewalk" (CPP 195) within his visionary scope, the America that was 
a poem in his eyes has a more episodic nature than in Whitman's rhapsodic catalogues, as in "The way, when we climb a mountain, / Vermont throws itself together" (CPP 476). So I see his relation to "a Whitmanian tradition" as that of a knowing and perhaps even wary adjacency, because Whitman's legacy would have constituted one of many aspects of reality that needed to be fended off, at least as an initial precaution. Stevens wrote about "poverty" as a quasi-metaphysical condition, where Whitman knew a little more about it as a fact of life. I would express my real sense of their difference in the suggestion that, for Whitman, the opportunity of "America" existed as an available plenitude, but for Stevens as an available vacancy, into which an angel might descend, or from which it has just departed. In Whitman's room, there might well be a chamber pot; in Stevens' house, there was a pure white rug, secondrate French paintings on the walls, first-rate wine secreted in the cellar, a library in packing crates upstairs, and, somewhere about, "the woman one loves or ought to love" (CPP 219). In Whitman's room there could be visitors, in Stevens' house there could not. "The stillness is all in the key of that desolate sound" (CPP 129); but, nonetheless, we learn to be repeatedly surprised by his poetry, as are bucks by firecat, as was Naaman Corn in Keney Park, when, delivered from the womb of his purposeless splendor, forth from the undergrowth comes Mr. Stevens, in his high-boot shoes.

\section{Lancaster University United Kingdom}

\section{Works Cited}

Brazeau, Peter. Parts of a World: Wallace Stevens Remembered; An Oral Biography. New York: Random House, 1983. Print.

Dickinson, Emily. The Letters of Emily Dickinson. Ed. Thomas H. Johnson. Cambridge: Harvard UP, 1979. Print.

James, William. "Address at the Emerson Centenary in Concord." Estimating Emerson: An Anthology of Criticism from Carlyle to Cavell. Ed. David LaRocca. New York: Bloomsbury, 2013. 285-90. Print.

Posnock, Ross. The Trial of Curiosity: Henry James, William James, and the Challenge of Modernity. New York: Oxford UP, 1991. Print.

Pound, Ezra. Selected Poems. Ed. T. S. Eliot. London: Faber, 1948. Print.

Stevens, Wallace. Letters of Wallace Stevens. Ed. Holly Stevens. 1966. Berkeley: U of California P, 1996. Print.

- Wallace Stevens: Collected Poetry and Prose. Ed. Frank Kermode and Joan Richardson. New York: Library of America, 1997. Print.

Whitman, Walt. Walt Whitman: An American Primer. Ed. Horace Traubel. Boston: Small, 1904. Print. 
-Walt Whitman: Poetry and Prose. Ed. Justin Kaplan. New York: Library of America, 1982. Print.

Williams, William Carlos. The Autobiography of William Carlos Williams. New York: New Directions, 1951. Print.

- The Collected Poems. Volume I: 1909-1939. Ed. A. Walton Litz and Christopher MacGowan. Manchester: Carcanet, 1987. Print.

. In the American Grain. 1925. New York: New Directions, 2009. Print. 